\title{
Effect of Two Heights and Three Intervals of Grazing on Stand of a Heavily Fertilized Star Grass Pasture ${ }^{1,2}$
}

\author{
José Rodríguez and Servando Silva
}

\begin{abstract}
The effect of two grazing heights and three grazing intervals on a stand of Star grass was determined over 2 consecutive years of grazing under humid tropical conditions.

A stand of Star grass was maintained better with high grazing (15-20 $\mathrm{cm}$ or 6-8 inches) at all grazing intervals than with low grazing (2.5-7.5 $\mathrm{cm}$ or 1-3 inches). The stand increased with length of grazing interval with low grazing up to 28 days and with high grazing increased only to the 21-day interval. It appears best to graze Star to a height of about 15-20 cm (6-8 inches) approximately every 3 weeks during seasons of flush growth and every 4 weeks during the slow growing winter season.
\end{abstract}

\section{INTRODUCTION}

Star grass (Cynodon nlemfuensis) 4 is rapidly becoming the most widely planted pasture grass in the humid region of Puerto Rico. Vicente-Chandler et al. (3) found that pastures of Star grass responded, in terms of beef production and carrying capacity, to applications of up to $3,180 \mathrm{~kg} / \mathrm{ha}$ (2,800 pounds per acre) of 15-5-10 fertilizer yearly. Caro et al. (2) found that Star grass pastures outyielded those of Pangola grass, producing over 1,500 $\mathrm{kg} / \mathrm{ha}$ (1,300 pounds) of gain in weight in liveweight per acre yearly when fertilized with $2,270 \mathrm{~kg} / \mathrm{ha}$ (2,000 pounds per acre) of $15-5-10$ fertilizer yearly. Caro et al. (1) found that yields of cut Star grass increased with length of harvest interval up to 60 days. Higher yields were obtained when Star grass was cut to a height of $0-7.5 \mathrm{~cm}(0$ to 3 inches) above the ground than when it was cut to a height of $15-20 \mathrm{~cm}$ ( 6 to 8 inches). No previous research has been conducted on the effect of grazing heights and intervals on the persistence of stand of well-fertilized Star grass pastures under actual grazing management.

1 Manuscript submitted to Editorial Board October 3, 1974.

2 This report covers work conducted cooperatively by the Agricultural Research Service, U. S. Department of Agriculture and the Agricultural Experiment Station, Mayagüez Campus, University of Puerto Rico, Río Piedras, P.R.

a Research Assistant, Agricultural Experiment Station and Agricultural Technician, ARS, USDA, Río Piedras, P.R., respectively.

A possible Puerto Rico cultivar of Cynodon dactylon. 
The present study was conducted for the purpose of determining the effect of two grazing heights and three grazing intervals on the stand of well-fertilized Star grass grazed by cattle over a 2-year period.

\section{MATERIALS AND METHODS}

An experiment was carried out at the Corozal Substation of the Agricultural Experiment Station under conditions typical of the humid mountain region of Puerto Rico. This Substation is located at an elevation of about 212 meters (700 feet) with mean monthly temperatures ranging from $18-31.6^{\circ} \mathrm{C}\left(64\right.$ to $\left.89^{\circ} \mathrm{F}\right)$. Annual rainfall is about $163 \mathrm{~cm}$ (65 inches), fairly well distributed throughout the year, except for a dry period from January through March. The soil is a deep, red, Corozal clay (Ultisol).

The following six treatments were tested using a randomized block design with four replications:

Grazing height: A (low), forage grazed to a height of $2.5-7.5 \mathrm{~cm}(1-3$ inches) from the ground; B (high), forage grazed to a height of $15-20 \mathrm{cms}$ (6-8 inches) from the ground.

Grazing frequency: 1) Grazed every 14 days; 2) grazed every 21 days; 3) grazed every 28 days.

Plots were $9.2 \times 9.2 \mathrm{~m}$ ( 30 feet $\times 30$ feet), each surrounded by a barbed and chicken wire fence to prevent cattle from grazing adjacent plots. The soil was limed to about $\mathrm{pH} 5.5$, and $2,270 \mathrm{~kg} / \mathrm{ha}(2,000$ pounds per acre) of 15-5-10 fertilizer were applied yearly in four equal applications to all plots.

At the intervals specified, two Holstein heifers grazed the grass to the required height in each plot which they accomplished in 1 to 2 days.

A pure stand of Star grass was established in all plots at the start of the experiment. At the end of the first year of grazing the plots were weeded and left ungrazed until a pure stand of Star was re-established. The percentage of Star in each plot was estimated visually by a team composed of the authors and two associates at the end of each year in terms of the total area of ground covered by this grass.

\section{RESULTS AND DISCUSSION}

At all grazing intervals a much better stand of Star grass was maintained in all plots with high grazing than with close grazing. Plots with high grazing had an average of 75 percent Star grass after the first year compared to only 48 per cent in those grazed closely. At the end of the second year the plots with high grazing had an average of 56 per cent Star grass, while plots closely grazed had only 33 percent (fig. 1).

The close grazed stand of Star increased with length of harvest interval. At the end of the first year the low grazed plots averaged 27, 48, and 69 
per cent with 14-, 21-, and 28-day grazing intervals, respectively (fig. 1). At the end of the second year the stand of low grazed Star also increased sharply with increasing length of grazing interval, averaging 10,33 and 56 percent with 14-, 21- and 28-day grazing intervals, respectively.

With high grazing the effect of length of harvest interval was less marked. At the end of the first year, high grazed plots averaged 54, 84 and 89 percent
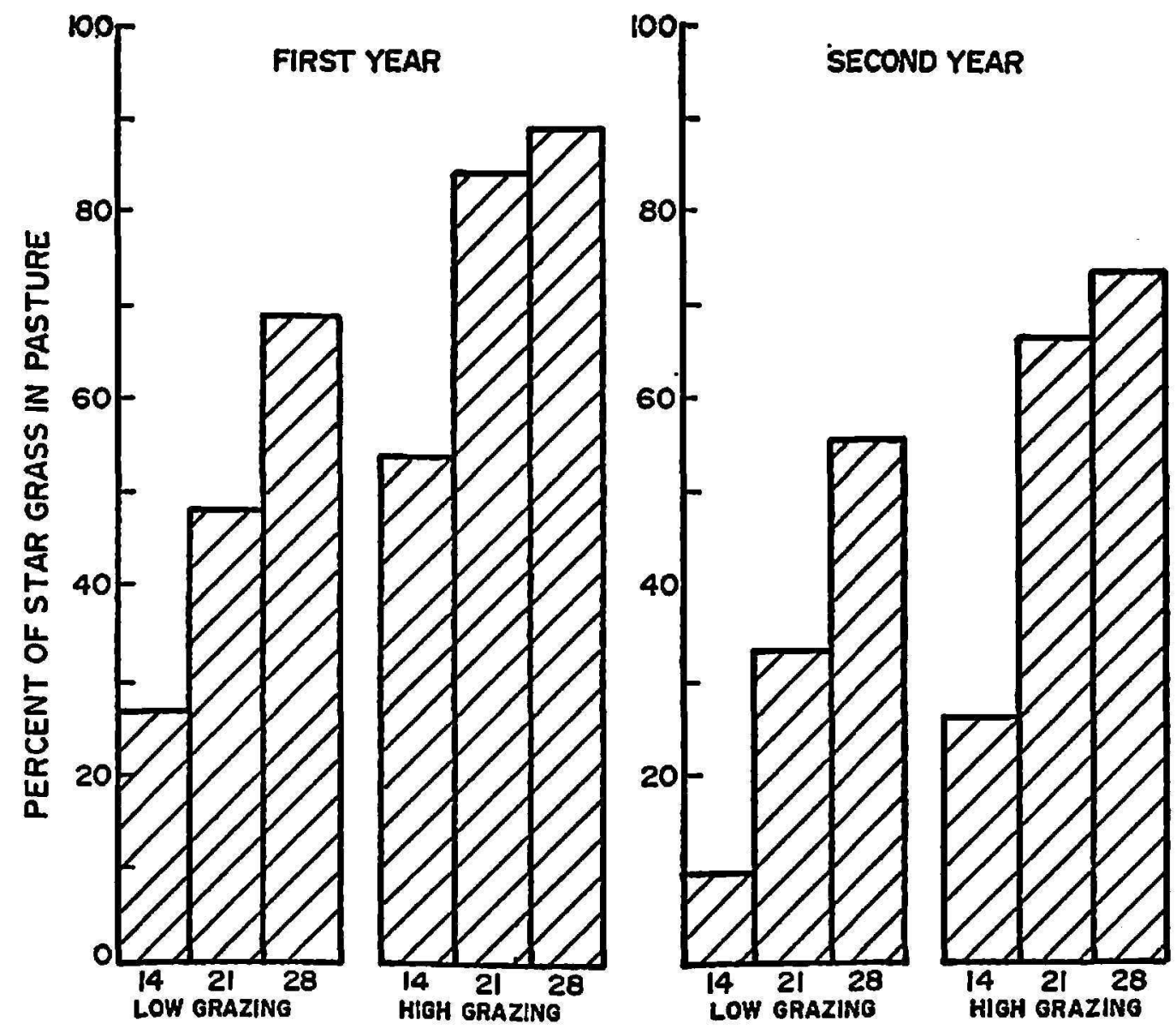

GRAZING INTERVALS (DAYS)

Fig. 1.-Effect of grazing height and interval on stand of Star grass at the end of the first and second years of grazing at Corozal.

Star when they were grazed at 14-, 21-, and 28-day intervals, respectively. At the end of the second year the high grazed plots averaged 26,67 and 74 percent Star when grazed every 14,21 and 28 days, respectively.

The better stand maintained with high grazing can be attributed to the greater photosynthetic area remaining after grazing, enabling the grass to recover more rapidly. Close-grazed grass must draw on its root reserves to resume growth after each grazing. The use of longer grazing intervals naturally would be expected to partially prevent the depressing effect of close grazing on yield. 
With the much longer cutting intervals used by Caro et al. (1) this factor is relatively unimportant and higher yields of Star are obtained by cutting close to the ground.

It can be concluded that to maintain a good stand and therefore high yields of Star grass, pastures should be grazed to about $12-20 \mathrm{~cm}$ from the ground (6-8 inches) about every 3 weeks during seasons of flush growth and about every 4 weeks during the winter season of slow growth.

\section{RESUMEN}

Se determinó el efecto de dos ulturas de pastoreo y tres intervalos entre pastoreos en el percentaje de yerba Estrella en un pasto inicialmente compuesto totalmente de esta yerba.

Al final, tanto del primer año de pastoreo como del segundo, el porcentaje de la yerba Estrella fue mucho mayor cuando la yerba se pastoreó hasta $15-20 \mathrm{~cm}$. (6-8 pulgadas) de altura que cuando se pastoré de $2.5-7.5 \mathrm{~cm}$. (1-3 pulgadas) de la tierra. Por otro lado, el porcentaje de yerba Estrella aumentó señaladamente según aumentó el intervalo entre pastoreos hasta 28 días cuando la forrajera se pastoreó hasta 2.5$7.5 \mathrm{~cm}$. (1-3 pulgadas) de la tierra y hasta 21 días cuando se pastoré hasta $15-20 \mathrm{~cm}$. (6-8 pulgadas).

Parece recomendable pastar la yerba Estrella hasta una altura de unos $15-20 \mathrm{~cm}$. (6-8 pulgadas) cada 3 semanas aproximadamente durante épocas de crecimiento rápido y cada 4 semanas en invierno durante la época de crecimiento lento.

\section{LITERATURE CITED}

1. Caro-Costas, R., Abruña, F., and Figarella, J., Effect of nitrogen rates, harvest intervals and cutting heights on yields and composition of Star grass in Puerto Rico, J. Agr. Univ. P.R. 56(3): 267-79, 1972.

2. - - - , and Vicente-Chandler, J., Comparison of heavily fertilized Pangola and Star grass pastures in terms of beef production and carrying capacity in the humid mountain region of Puerto Rico, J. Agr. Univ. P.R. 56(2): 104-9, 1972.

3. Vicente-Chandler, J., Abruña, F., Caro Costas, R., Figarella, J., Silva, S., and Pearson, R. W., Intensive Grassland Management in the Humid Tropics of Puerto Rico, Agr. Exp. Sta., Univ. P.R. Bull. 233, Feb. 1974. 